\title{
Pediatric andrology: the andrological patient from infancy to adulthood. Prevention interventions: how and when
}

\author{
Salvatore Bonforte
}

\author{
From 71st Congress of the Italian Society of Pediatrics. Joint National Meeting SIP, SIMGePeD, Study Group \\ on Pediatric Ultrasound, SUP Study Group on Hypertension \\ Rome, Italy. 4-6 June 2015
}

Sonography, a non-invasive, quick method without biological impact on the gonad, has greatly improved the diagnostic possibilities; it is the gold standard for the male genital system (gonads and genito-urinary tract) and in fact has oriented the prevention interventions [1].

It recognizes almost $100 \%$ of scrotal lesions and their solid, liquid or complex nature. It has allowed to overcome the limits of traditional diagnostic methods for gonads like palpation, transillumination, and the Prader orchidometer for volumetric assessment. In fact, compared to this, sonography allows a more accurate volume measurement, expecially in small testicles; a correlation between measurements made with the orchidometer and those made with ultrasounds was found only for testicular volumes over $4 \mathrm{cc}$. [2].

Measurement of testicular volume is a fundamental element in pediatric andrology for evaluating puberty onset and progression. Furthermore, the sonographic exam is one of the best tools for assessing testicular pathologies like torsion, undescended testis, varicocele and in general in pathologies involving male genitalia; these cases can show significant variations of testicular volume. Testicular growth restriction may have relevant clinical implications for future testicular function [3].

The limits of traditional tools, like the orchidometer or the ruler for the measurement of pre-puberal testicle, are easy to identify:

- The smallest pearl in Prader orchidometer is $1 \mathrm{ml}$, while sonography allows to make measurements in the first years of life $(0,44 \mathrm{ml} \pm 0,03)$;

Correspondence: salvo.bonforte@alice.it Pediatra di famiglia ASP/3 Catania, Italy 
old with undescended, retractile and hydrocele testis - Usefulness of scrotal screening ultrasound. Early Human Development 2012, 88:185-189.

3. Ferlin A, Zuccarello D, Zuccarello B, Chirico MR, Zanon GF, Foresta C: Genetic Alterations Associated With Cryptorchidism. JAMA 2008, 300:2271-6.

4. Tasian G, Copp HL: Diagnostic Performance of Ultrasound in Nonpalpable Cryptorchidism: A Systematic Review and Meta-analysis. Pediatrics 2011, 127:119.

doi:10.1186/1824-7288-41-S2-A10

Cite this article as: Bonforte: Pediatric andrology: the andrological patient from infancy to adulthood. Prevention interventions: how and when. Italian Journal of Pediatrics 2015 41(Suppl 2):A10.

Submit your next manuscript to BioMed Central and take full advantage of:

- Convenient online submission

- Thorough peer review

- No space constraints or color figure charges

- Immediate publication on acceptance

- Inclusion in PubMed, CAS, Scopus and Google Scholar

- Research which is freely available for redistribution

Submit your manuscript at www.biomedcentral.com/submit 